\title{
Dos estudos de Epstein sobre as "nephrites chronicas parenchymatosas"
}

Trabalho lido na Sociedade Arnaldo Vieira de
Carvalho pelo doutorando João Alves Meira.

O nome de Epstein junto ao titulo deste trabalho e a natural e reconhecida falta de autoridade de um estreiante na literatura medica plena e satisfactoriamente justificam sejam as primeiras palavras da nossa modesta communicação constituidas pela citação das palavras de Gasendi: "Ce ne sont pas mes lumieres que je cherche de repandré, ce sont celles d'autrui."

Effectivamente, não pretendemos, com o que se segue, senão resumir e expor de modo tão claro quanto nos for possivel o modo de ver de Albert A. Epstein sobre tão importante capitulo da pathologia, como é o das nephrites.

A nephropatologia clinica offerece pontos de vistas tão diversos, segundo a escola seguida, que achamos, de conveniencia, trazer-vos esta communicação, baseada e colhida dos estudos do citado scientista norte americano, visto os mesmos se afastarem grandemente do modo de ver da escola franceza, que é a geralmente seguida entre nós e acceita sem contestação na sua quasi totalidade. D'ahi se infere que o unico interesse deste trabalho, que é só de divulgação, reside em apontar os pontos dissonantes e dispares encerrados nas doutrinas francezas, de todos vós conhecidas e nas d'aquelle medico do "M.te Sinai Hospital" senão de todos vós, pelo menos de alguns, ignoradas.

Partindo do estudo do chimismo do serum sanguineo e dos varios derrames liquidos susceptiveis de se accumular nas cavidades serosas do organismo e infiltrar o tecido sub-cutaneo, chegou Epstein a verificações muito interessantes sobre o assumpto em consideração. Assim é que após o estudo da composição sanguinea nos casos normaes, onde obteve valores semelhantes aquelles registrados pelos trabalhos classicos, passou Epstein á constatação das variações soffridas pelos componentes do serum sanguineo nos varios estados pathologicos. 
No estudo do chimismo do sangue e das effusões serosas preoccupou-se Epstein dos seguintes constituintes: proteina total, nitrogenio incoagulavel e não proteinico, globulina total, pseudo globulina, englobulina, albumina, chloretos, relação albumina-globulina e porcentagem da globulina em proteina.

As mais notaveis variações, encontradas nos casos pathologicos, affectam os constituintes proteinicos do serum. Em determinados casos a fracção globulina acha-se elevada, em quanto que a proteina total pode ser normal ou se achar muito abaixo da quantidade normal. Aggrupam-se do seguinte modo as molestias nas quaes se constata um augmento nas globulinas: 1) lesões cardiacas, no periodo asystolico. 2) affecções pulmonares de origem inflammatoria ou não. 3) Diabetes. 4) nephrite chronica parenchymatosa.

Nesta ultima affecção, a variação em estudo assume as maiores proporções e é onde se mostra mais patente. Assim é que o conteúdo globulinico é muito pronunciado podendo a globulina constituir quasi toda proteina, ou tanto quanto $95 \%$.

$\mathrm{Na}$ achylia gastrica simples, na tuberculose, na diabetes insipida e na nephrite chronica intersticial, o conteúdo da globulina é normal ou diminuido.

Nas molestias estudadas, os outros componentes do serum sanguineo apresentam variações de difficil apreciação e devida interpretação, mas de um modo geral pode-se dizer que o accumulo da agua e do sal occorria n'aquellas molestias em que a fracção globulina se achava augmentada.

Desse estudo verificou Epstein que grande differença existia entre as nephrites chronicas parenchymatosas, as nephrites chronicas intersticiaes e nephrites mixtas.

Ao contrario da nephrite chronica parenchymatosa, onde se observa a baixa da quantidade da proteina abaixo da minima normal e um augmento relativo da globulina em relação a albumina, augmento que n'um caso chegou a ser absoluto, na nephrite chronica intersticial a quantidade total da proteina colloca-se dentro do limites do normal e bem assim a relação albumina globulina tambem se conserva normal, havendo mesmo, por vezes, neste caso, uma tendencia da fracção globulina a cahir abaixo do normal.

Nas nephrites mixtas os resultados encontrados ora são identicos aos observados na nephrite chronica parenchymatosa, ora se approximam d'aquelles verificados na nephrite chronica intersticial. Contudo, nestes casos, a relação globulina-albumina pode ser encontrada elevada mas não attinge os valores observados na nephrite chronica parenchymatosa.

Com este ponto de partida, passou Epstein á verificar até que limite as affecções renaes localisadas reagem sobre a composição do sangue e sobretudo sobre o conteúdo proteinico do serum. Em primero lugar estudou as affecções genito-urinarias. 
Nos casos cirurgicos de natureza insignificante (varicocelle, orchite, etc.) verificou que a composição do serum sanguineo, inclusive os seus constituintes proteinicos, variava de accordo com os padrões normaes estabelecidos. N'um segundo grupo estudou os casos de hypertrophia da prostata e carcinoma da prostata e bexiga, e, este grupo é interessante, porque, pelo seu resultado, se pode aquilatar do allegado effeito da hypertrophia prostatica e consequente retenção de urina sobre a pathologia renal. Assim, pode-se controllar qual a repercussão de taes processos sobre a constituição chimica do sangue. Nos casos de hypertrophia da prostata (com ou sem nephrite chronica intersticial, que em alguns casos estava presente) a composição proteinica do serum sanguineo não se altera nem si modificam as proporções reciprocas mantidas entre uma fracção e outra (albumina-globulina). Por outro lado, o azoto incoagulavel e não proteinico do sangue mostra accentuadas fluctuações, algumas das quaes estão em correspondencia com o grau de defficiencia funccional dos rins.

Nos casos de affecções localisadas dos rins (hydronepheose, lithiase renal, pynephrose, abcesso perinephretico, pyelonephrite e tuberculose renal unilateral) a lesão renal não repercute sobre a composição das serum proteinas; mas é necessario se excluir o papel que representa o processo infeccioso localisado no rim, como aliás, em outro qualquer orgam, e afastar a destruição do tecido renal e diminuição da funç̧ão do rim, sem o que não se pode apreciar devidamente o effeito de taes processos infecciosos, localisados, sobre o serum sanguineo.

Quasi todos os casos estudados neste grupo representam um processo inflamatorio pyogenico do rim. $\mathrm{O}$ factor infecção deve ser afastado por causa do seu reconhecido effeito sobre a composição chimica do serum sanguineo, pois, se sabe que nos processos infecciosos pyogenicos as globulinas do sangue são augmentadas e o augmento da relação porcentual globulina-albumina e da proteina total parece ser proporcional á duração e extensão do processo infeccioso. Isto foi muito bem documentado por Epstein com exemplos concretos, nos quaes o estudo do chimismo sanguineo foi feito durante a evolução do processo infeccioso localisado ao rim. De outro lado, tambem com exemplos comprovantes, mostrou Epstein a relação existente entre a retenção dos productos nitrogenicos consumidos e o estado funccional dos rins.

De modo que, em conclusão, se pode dizer que nos casos de affecções localisados aos rins as modificações apresentadas pelo serum sanguineo são de duas ordens: uma, em relação á constituição proteinica do serum que é dependente da infecção e outra concernente ao azoto não proteinico, resultando essa modificação da diminuição funccional do rim e variando com a quantidade da destruição da substancia renal. 
Até aqui só nos referimos ás constatações feitas pelo estudo da composição chimica do sangue. Vejamos agora a que conclusões chegou Epstein do estudo chimico das effusões serosas.

Sob o ponto de sua constituição chimica estudou Epstein as effusões cutaneas, pleuraes, abdominaes e o liquido da hydrocelle. Os liquidos tiveram origens diversas, assim: nas effusões cutaneas foram examinados aquellas de origem nephritica e cardio nephritica; os derrames pleuraes foram obtidos de estados inflammatorios (de etilogia desconhecida e tuberculose) e não inflammatorios (nephrite e neoplasmas intra-thoraxicos); os liquidos abdominaes eram provenientes de casos de nephrites puras, cardionephrites, cirrhose do figado, lesões cardiacas, tuberculose e neoplasmas abdominaes. Foram feitos muitos estudos comparativos do chimismo do sangue e dos liquidos dos derrames e algumas das conclusões a que chegou Epstein são as seguintes: A composição dos differentes derrames é differente segundo a localisação e segundo a molestia na qual se produziu a effusão. Assim as effusões subcutaneas são totalmente differentes, em sua composição, dos liquidos abdominaes ou pleuraes. Do mesmo modo, o liquido de origem nephritica differe d'aquelles de origem cardiaca ou outras.

As effusões cutaneas encerram baixo conteúdo proteinico e pouca quantidade de azoto incoagulavel; a globulina prepondera nesses liquidos sobre a albumina não existindo porem parallelismo entre a composição proteinica da effusão e do sangue nas effussões de origem nephritica. Um certo parallelismo existe nos casos de effusão cardio nephritica. Os chloretos avantajam-se sobre o normal, mas o seu valor é menor que aquelle encontrado no sangue. As collecções liquidas das cavidades serosas são mais ricas em seu conteúdo proteinico. Desse grupo de liquidos, os pleuraes são os que attingem maiores valores, sendo a proteina nelles presente quasi a mesma que a mostrada pelo sangue normal. $\mathrm{O}$ azoto incoagulavel é uniformemente baixo e os chloretos variam com a natureza do caso. Os liquidos de outras origens que não a inflammatoria apresentam um conteúdo proteinico identico ou maior que aquelle do serum sanguineo. A maior relação globulina-albumina foi encontrada num liquido pleural de origem nephritica. Os liquidos abdominaes são em geral mais pobres em proteina do que os pleuraes. Os maiores valores em proteina são encontrados naquelles liquidos de origem cardiaca mas as proporções globulina-albumina são inferiores aquellas dos liquidos pleuraes ou do serum sanguineo dos casos que lhe correspondem.

O nitrogenio incoagulavel é baixo. No liquido abdominal de origem nephritica, no caso estudado por Epstein, o conteúdo proteinico é baixo e todo elle constituido de globulina ( $100 \%$ ) o que toma maior interesse quando comparado com os valores obtidos nas analyses do serum sanguineo dos casos nephriticos.

Os liquidos abdominaes examinados nos casos cardio nephriticos approximam-se muito em seus resultados d'aquelles de origem pura- 
mente cardiaca. Digno de nota pois é a hypoalbuminose, praticamente absoluta, dos liquidos de edema de origem nephritica.

Das differenças encontradas na constituição chimica dos derrames tirou Epstein elementos para documentação da theoria extra renal do edema.

Vê-se do que acabamos de dizer que as modificações do serum sanguineo e effussões, assumem certas particularidades interessantes nos estados pathologicos sendo aquellas soffridas pela composição proteinica do serum as mais pronunciadas, principalmente quando comparadas entre si as que se operam nos casos de nephrite chronica parenchymatosa e nephrite chronica intersticial.

Epstein é de opinião que as modificações apontadas occorrendo na composição proteinica do serum nas differentes molestias não são accidentaes, mas são o resultado de bem definidas influencias agindo sobre o sangue. "Contrapondo-se, diz Epstein, as pesquizas no serum de pacientes com nephrite chronica intersticial e com nephrite chronica parenchymatosa, conclue-se que as duas affecções são geneticamente differentes com respeito ao sangue, e que a modificação na composição proteinica do serum sanguineo toma uma parte directa na producção de algumas das manifestações clinicas dos dois typos de affecção renal. A composição da urina e do serum sanguineo (chloretos e productos nitrogenicos consumidos) na nephrite chronica intersticial depende do grau da diminuição da funç̧ão renal; emquanto que na nephrite chronica parenchymatosa o chiminismo da urina, a retenção do liquido e do sal no organismo, e, em grande extensão o caracter da lesão nos rins, são devidas ás modificações occorrendo no sangue."

Com o decorrer deste trabalho procuraremos esclarecer o que acabamos de citar e para melhor comprehensão do assumpto vamos ver o que se entende pela chamada nephrite chronica parenchymatosa.

O termo "nephrite chronica parenchymatosa" é uma denominação que abrange differentes typos de affecções renaes que embora apresentem alguns pontos de contacto offerecem entretanto, certas distinç̧ões e caracteristicos capazes de as identificar e separar, pelo menos, nos casos em que ellas se apresentam nos seus typos puros. Assim é que por "nephrite chronica parenchymatosa" comprehendese a nephrite diffusa ou melhor a glomerulonephrite, a amyloidose renal e a chamada nephrose chronica. A razão pela qual as tres entidades morbidas referidas tem sido aggrupadas sob um mesmo titulo reside no facto que certas manifestações clinicas são communs a todas ellas, isto é, a oliguria, a albuminuria e o edema. A nephrose chronica graças a certos caracteristicos clinicos, alliados a outros tantos biochimicos aquilatados do estudo da composição sanguinea e do exame das urinas, juntos a historia do doente e informações anatomia-pathologica foi verificada tratar-se de uma entidade morbida distincta e porisso perfeitamente separavel d'aquelle grupo das 
nephrite chronicas retulados com o titulo de "nephrite chronica parenchymatosa" Verificou-se que na nephrite chronica parenchymatosa existem pelo menos dois typos que podem ser distinctamente identificados: $10^{\circ}$ ) aquelle no qual principalmente os glomerulos são lesados com compromettimento secundario dos tubulos ou do tecido intesticial, ou tanto um como outro, e que realmente representa uma inflammação do glomerulo - uma glomerulonephrite.

$2 .^{\circ}$ ) aquelles casos onde a lesão predominante se assesta nos tubulos e nos quaes os glomerulos não são lesados sendo a lesão tubular puramente degenerativa.

$\mathrm{A}^{\prime}$ este ultimo processo, degenerativo tubular, Frederich Müller propoz o nome de nephrose. O nome dado por Müller embora não muito feliz, e aliás muito discutido, foi entretanto adoptado por muitos estudiosos do assumpto. (Volhard e Fahr, Munk, Richter etc).

A lesão nos rins nestes casos foi provado pelas autopsias revestir um typo degenerativo adeantado (Volhard e Fahr).

Os estudos de Epstein tendem a sustentar a entidade morbida desse typo de lesão renal, baseado nas constatações sobre o chimismo sanguineo e nos derrames serosos.

Como adeante veremos, a nephrose chronica assume certas feições que a catalogam entre as desordens de origem metabolica; Epstein prefere denominal-a de "diabetes albuminuricus", visto o termo nephrose attribuir papel de maior realce aos rins do que aquelle que realmente elles representam no estado morbido em consideração, por isso que os symptomas apresentados pelos doentes são de origem extra-renal e as lesões renaes serem a consequencia de pertubações de ordem geral.

Etiologia. - A etiologia da nephrose chronica é obscura. Suas relações com as molestias infecciosas não são bem definidas. Munk discutindo a nephrose lipoidica attribue á syphilis papel de primordial importancia como factor etiologico. Para Epstein, segundo sua experiencia, a nephrose é um estado independente e nada tem com a syphilis, a coexistencia de uma historia de syphilis ou de uma reacção de Wassermann positiva com uma nephrose chronica não significando que esta seja necessariamente o resultado da syphilis. Para Epstein, nas mulheres, a gravidez está em nexo etiologico com a nephrose chronica que se desenvolve durante o curso ou após a prenhez, correndo alguns dos symptomas muitas vezes frequentes, em desaccordo com o quadro typico (hypertensão) por conta das perturbações endocrinas associadas, no processo gravidico, á nephrose.

O myxedema e os estudos hypothyroidianos representam, segundo Epstein, papel de importancia como factor etiologico visto a sua frequente coexistencia e a presença na nephrose de caracteristicos daquelles estados. Acomette de preferencia os individuos jovens e sua maior incidencia sobre os pobres parece indicar se trate de uma perturbação nutritiva. 
Em summa, para Epstein, a nephrose chronica é o resultado de uma profunda perturbação metabolica, de causa desconhecida, guardando entretanto a gravidez, o myxedema e os estudos hypothyroideos relações estreitas com o processo morbido.

Symptomatologia - Formas Clinicas - Diagnostico DIFFERENCIAL. - A nephrose chronica é uma molestia de inicio lento, moroso e cuja evolução se processa gradualmente. Accommette os individuos jovens e frequentemente as creanças.

As suas principaes manifestaçōes clinicas são as seguintes:

Pallidez accentuada da pelle, em desaccordo com a anemia, que não existe ou é ligeira. A perda do appetite e uma sensação de fadiga enfileiram-se entre os symptomas precoces. A dor nas costas, si bem que em muitos casos seja apresentada, não é um symptoma constante. Do quadro clinico da nephrose chronica fazem parte tambem a cephalea, os vomitos e a diarrhea.

Os symptomas subjectivos podem estar ausentes, sendo á principio a molestia distituida de grandes manifestações clinicas.

Contudo, com o evoluir do processo morbido se estabelecem a oliguria e o edema. A principio uma inchação das palpebras e dos tornozellos alliada a pallidez, são os unicos symptomas que chamam a attenção do paciente. Invariavelmente, entretanto, desenvolve-se o edema e a oliguria: o edema assume, na molestia em consideração, o seu mais alto grau chegando á chemosis e á anasarca, e constitue a principal manifestação clinica da nephrose chronica.

$\mathrm{O}$ apparelho cardio-vascular é poupado mostrando-se normal ao exame. Não se constata hypertensão arterial; a pressão sanguinea em regra é normal. O coração não șe mostra augmentado de volume, aos processos de exploração clinica não se verificando nenhuma hypertrophia do ventriculo esquerdo. O exame das urinas offerece importantissimos informes. Sua quantidade, em 24 horas, é muito reduzida; a densidade especifica é alta, o que attesta a conservação do poder de concentração dos rins. A albuminuria é intensa attingindo á 10-28 até $50 \%$. Ao lado da albumina constatase na urina, ás vezes, a presença de cylindros (hyalinos, granulosos, lipoides). A cylindruria entretanto não coexiste obrigatoriamente com a albuminuria. A ausencia de hematias na urina é a regra e constitue importante signal para o diagnostico. No estado inicial, pre-edematoso, da molestia a emissão das substancias excretadas com a urina pode ser normal, mas as provas de exploração funccional revelam, muita vez, deficiencia renal que se traduz pela retenção dos chloretos, do azoto e uma diminuida excreção da sulphophenolphataleina. Ainda no estado pre-edematoso da molestia, e só neste periodo, póde occorrer a retenção da agua no sangue (hydremia) e nos tecidos do corpo (outros que não o sub-cutaneo) que são capazes de armazenar muito liquido antes de se mostrar definitivamente a presença do edema. Nos casos completamente evoluidos a retenção dos chloretos e do azoto pode ser accentuada e o 
exame do sangue pode deixar de dar taes informes o que sem duvida é devido. principalmente no estado edematoso da molestia, á grande distribuição das substancias retidas por todo o corpo nos tecidos encharcados.

Os estudos chimicos de Epstein, a que de começo nos referimos, mostraram que os constituintes não proteinicos dos derrames approximam-se tanto em quantidade como em qualidade d'aquelles do sangue. Demais, Denis e Minot verificaram que os constituintes não proteinicos dos liquidos (que são crystalloides taes como a uréa, acido urico, creatinina) occorrem na mesma concentração tanto nos exudatos e transudatos como no sangue. Alem disso, observaram que a ausencia da augmentada concentração dos substancias azotados não proteinicos no sangue, nos casos de nephrose, é provavelmente devida á distribuição destas substancias por todo o organismo o que é evidenciado pelo facto que, tanto no periodo pre-como no post edematoso da molestia, se verifica uma maior concentração dos productos azotados consumidos e dos chloretos. Assim pelo que ficou dito, as estimações das substancias soluveis no sangue, em todos os casos associados com derrames ou edema, não registram exactamente a quantidade de taes substancias que se acham retidas no corpo.

Isto, segundo Epstein, é de importancia quando se procura interpretar as provas funccionaes dos rins.

Nos casos adeantados de nephrose chronica occorrem geralmente certos symptomas taes como: cephaléa, perturbações visuaes, convulsões e coma, que são attribuidos ordinariamente á "uremia" Mas na nephrose chronica estes symptomas "uremicos" parecem devidos ao edema do systema cerebro espinal e não a qualquer envenenamento ou intoxicação pelas substancias urinarias retidas.

A verdadeira "uremia, de pathogenia ainda não de todo esclarecida parece, em parte, devida á retenção ou concentração no sangue dos productos azotados consumidos, em parte, á retenção dos acidos de saes inorganicos e redução da reserva alcalina do sangue. Na nephrose chronica, excepção feita para as phases pre e post edematosas, a retenção dos productos nitrogenicos consumidos não se opera, a concentração d'aquellas substancias no sangue não occorre.

A' luz dos estudos modernos o diagnostico da nephrose chronica hoje não é só baseado na historia do doente, exame clinico e exames da urina e dosagem da uréa no sangue. As nephroses chronicas offerecem uma feição bio-chimica particular e o exame do sangue revela na nephrose chronica alguns caracteristicos implortantes sobre os quaes Epstein muito tem insistido.

$\mathrm{O}$ exame da composição do sangue registra nestes casos o seguinte quanto ao conteúdo proteinico do serum sanguineo: a proteina total, via de regra, é baixa; quando nas proximidades do normal quasi toda ella é constituida por globulina; as albuminas do 
serum mostram-se muito inferiores á taxa normal; observa-se sempre, um augmento relativo da globulina com inversão da proporção normal albumina-globulina; assim a globulina que representa, nas condições normaes um terço da proteina normal ou seja, em media, $37 \%$ passa, na nephrose chronica a representar tanto quanto $89,2 \%$.

Ao lado das modificações observadas por Epstein sobre o conteúdo proteinico do serum sanguineo, nota-se na nephrose uma lipoidemia que se manifesta pela opalecencia do serum, com apparencia chylosa do mesmo; o conteúdo cholesterinico do sangue na diabetes albuminuria de Epstein attinge a cifras muito altas e a hypercholesterinemia constitue um caracteristico de importancia fundamental. $\mathrm{Na}$ nephrose chronica, finalmente, os estudos sobre o metabolismo basal tem mostrado, a existencia de uma baixa do processo metabolico. Resumido são os seguintes os symptomas e elementos diagnosticos que compôem o quadro clinico, da nephrose chronica: Pallidez, edema (anasarca) oliguria, urinas escassas com densidade especifica alta, albuminuria com ou sem cylindruria, ausencia de hematias, redução dos chloretos. Ausencia de hypertensão e de augmento do volume do coração.

Baixo conteúdo proteinico (proteinas totaes) do serum sanguineo com notavel diminuição da albumina; predominio da globulina; inversão da proporção normal albumina-globulina; lipoidemia; hypercholesterinemia.

Nos casos puros de nephrose chronica o diagnostico se faz com o auxilio dos dados anamnesicos, symptomas objectivos e principalmente pelo contingente fornecido pelo laboratorio-analyse de urina e estudo dos componentes proteinicos do serum sanguineo e dosagem da cholesterina sanguinea.

A molestia póde passar, de inicio, despercebida pelo doente, e o medico, por acaso, descobrindo a albuminuria e constatando as variações da composição sanguinea, que aliás, á principio, podem ser ligeiras ou insignificantes, deve pensar na nephrose chronica. A evolução posterior do caso, se therapeutica racional não for administrada ou seguida, pelo paciente, com o desenvolvimento de outras manifestações, taes como o edema e oliguria, vem, muitas vezes, confirmar o diagnostico feito anteriormente.

Epstein descrevendo os typos clinicos da nephrose chronica estudou aquelles nos quaes a entidade morbida evolue:

a) na sua forma pura, tal como a registramos; $b$ ) em associação com o myxedema revestindo então o typo endocrinico; $c$ ) nephrose na gravidez; $d$ ) nephrose em associação com a diabetes; e) nephrose primaria com nephrite diffusa superajuntada.

a) ja dissemos muito do typyo puro da nephrose chronica, os seus symptomas e quaes os meios de diagnostico.

b) a nephrose chronica no typo endocrino se acha associada a estados de hypothyroidismo ou ao myxedema. O diagnostico nestes casos se faz graças aos symptomas das duas molestias presentes: sig- 
naes hypothyroidianos ou myxematosos, de um lado, symptomas de nephrose chronica de outro. Quando tratarmos mais adeante da pathogenia veremos qual a relação da glandula thyroide em uma e outra entidade morbida. O reconhecimento deste typo é importante para a administração therapeutica indicada a seguir.

c) A gravidez, como foi dito atrás, na opinião de Epstein, mantem certas relações etiologicas com a nephrose chronica, que se desenvolve durante ou após o decurso de uma prenhez. Tem se attribuido que a perturbação renal que muitas vezes se desenvolve durante ou após a gravidez é o resultado de uma intoxicação especial e ha razão para se crer seja o resultado da dysfuncção de uma ou mais gladulas de secreção interna. O facto é que ha casos nos quaes a nephrose chronica que se desenvolve na gravidez está associada a uma perturbação de uma glandula endocrinica especifica tal como a thyroide. De outro lado, nestes casos, a hypertensão pode ser constatada, mas ella parece correr por conta dos phenomenos endocrinos associados, peculiares ao processo gravidico, lembrando-se que mesmo nas condições ordinarias a cessação das regras é seguida de uma tendencia a elevação da pressão sanguinea. $\mathrm{Na}$ nephrose associada a gravidez, a interferencia dos factores endocrinos ainda se evidencia pelo facto da melhoria, ou mesmo o desapparecimento, que se observa nos signaes de nephrose (edema, albuminuria) com a cessação da lactação e a volta da menstruação.

d) $\mathrm{Na}$ diabetes mellitus muita vez se desenvolve uma nephrose chronica. Aliás, na diabetes tanto evolue a nephrose como pode occorrer a verdadeira nephrite.

Clinicamente, entretanto, constata-se os elementos diagnosticos ora da nephrose, com excepção do edema que só vem em geral tardiamente, ora da nephrite.

A ausencia do edema na nephrose chronica dos antigos portadores de diabetes mellitus é um phenomeno muito interessante e de interpretação difficil. Comtudo, a diurese abundante que geralmente acompanha a glycosuria nada tem com este phenomeno, visto o mesmo estado substituir quando os pacientes são aglycosuricos. Parece que a hyperglycemia representa neste particular um papel de maior importancia. O papel hygroscopico do assucar é bem conhecido e provavelmente exerce uma definida influencia sobre as trocas aquosas entre o sangue e os tecidos o que até certo ponto viria demonstrar que a perda do poder osmotico do sangue conduz posteriormente a retenção dos liquidos pelos tecidos com a consequente formação do edema.

e) o diagnostico differencial entre a nephrose chronica e a glomerulonephrite é facil quando nos achamos em frente de casos puros, não complicados.

Assim, a grande edemacia, a oliguria, intensa albuminuria com ou sem cylindrurica concommunitante, a hypercholesterinemia e as modificações assignaladas, no contúdo proteinico do sangue, nos conduzem ao diagnostico da nephrose chronica. 
A hypertensão, a hypertrophia do ventriculo esquerdo, a presença de hematias na urina, a retenção dos productos azotados nos levam ao diagnostico da glomerulonephrite.

A historia de uma angina ou infecção focal anterior ou de uma nephrite aguda anterior tambem são elementos que servem para o diagnostico differencial e conduzem ao diagnostico de nephrite. Todavia estes dados precisam, para ter valor, não serem isolados de qualquer outra manifestação verdadeiramente nephritica.

Nos casos mixtos de nephrose primaria, com nephrite secundaria, ou vice-versa, os symptomas apresentados sommam-se e o prognostico então varia de accordo com o grau da lesão renal.

Considerando o diagnostico differencial seja-nos licito, de passagem, dizer que na opinião de Epstein a nephrose aguda que faz seguida a um envenenamento por toxicos mineraes (bichloreto de mercurio por exemplo) ou que se segue a um processo toxi-infeccioso agudo, febril, differe da nephrose chronica não só sob o ponto de vista de alguns symptomas apresentados, mas tambem sob o ponto de vista da interpretação pathogenica. Assim, emquanto a nephrose aguda resultante d'aquelles processos corre parelha com o processo toxico infeccioso causal, que determinou a lesão renal e cessa com o seu afastamento, a nephrose chronica é determinada por uma perturbação metabolica geral e não provem de uma nephrose aguda.

Pathogenia. - Como ja dissemos, dos estudos de Epstein resalta que a nephrose chronica é o resultado de uma profunda perturbação metabolica. Vejamos qual a interpretação pathogenetica emprestada por Epstein aos diversos symptomas e caracteristicos da nephrose chronica. Todos elles, seja dito de passagem, segundo o citado scientista, são justificados por factores extra-renaes.

A albuminuria, que é intensa nestes casos, é o resultado da alteração soffrida por algumas ou todas cellulas do organismo, ou de uma modificação (chimica, physica ou biologica) da propria serumproteina; d'ahi resulta a incapacidade do organismo em aproveitar as proteinas para o fim do metabolismo proteico, excretando-as pelos rins como uma substancia extranha, do mesmo modo como os rins excretam outras substancias circulantes no sangue que são extranhas ou que não são mais utilisaveis.

Assim como a glycosuria da diabetes mellitus é o ultimo resultado de uma perversão dos hydratos de carbono, assim tambem na "diabetes albuminuricus" a albuminuria resulta de uma perversão nas relações metabolicas das proteinas sanguineas e as das cellulas do corpo. O que se opera é uma perturbação qualitativa cuja natureza ainda de todo não é determinada. Em summa, a albuminuria é o resultado de uma "excreção activa" da serum proteina pelo rim.

A persistencia da albuminuria, que na nephrose é notavel, e a sua não substituição pelas albuminas da alimentação, acarreta, com o tempo, uma baixa do conteúdo proteinico do sangue, tal como citado nos estudos sobre o chimismo do sangue na nephrose chronica. 
A globulina elevada que se encontra nos mesmos casos, e que se manifesta pela inversão albumina-globulina, é explicada, em parte, pela differença na proporção da excreção das varias proteinas do sangue, e, em parte, na modificação na formação da globulina ou na desintegração cellular.

A lipoidemia manifestada principalmente pelo aspecto chyloso do serum dos nephroticos e pela hypercholesterinemia é de interpretação difficil e de todo ainda não esclarecida. Dos lipoides o que foi mais estudado foi a cholesterina.

Mesmo no sangue normal a origem da cholesterina não é definitivamente conhecida; as opiniões se dividem, para uns sendo de origem exogena e para outros de origem endogena. A cholesterina soffre variações accentuadas em muitos estudos pathologicos e em alguns, parece independer de causa externa, como na nephrose chronica e na diabetes mellitus. Nestas molestias, ella se acha associada á desordens metabolicas, sendo que na nephrose chronica assume proporções avantajadas e desempenha, porisso, papel de fundamental importancia. A hypercholesterinemia parece manter relações com a actividade de certas glandulas de secreção interna, taes como a supra renal e a thyroide. A lipoidemia da nephrose chronica differe d'aquella da diabetes mellitus, visto a lipoidemia da diabetes mellitus depender, em grande parte, da não combustão do assucar, ou seja o resultado de uma excessiva absorpção e uma pervertida utilisação da gordura, estando associada frequentemente com a acidose. A lipoidemia da nephrose chronica não é associada a cetose e não é devida ao accumulo da gordura ingerida porque a restricção desta não determina uma queda do conteúdo lipoidico do sangue, a eliminação da gordura na dieta não influenciando sobre a lipoidemia da nephrose chronica. Talves seja mais licito attribuir essa lipoidemia á outras fontes, á mobilisação da gordura do corpo, mormente porque taes casos mostram extrema magreza, que é mascarada pelo edema conconcomittante e que se patenteia quando o desapparecimento da infiltração edematosa dos tecidos se opera.

Aliás, a degeneração do tecido póde contribuir com a sua quota de material lipoide para o sangue, consoante os estudos de Mlle. Kock e Voegetlin, citados por Epstein.

Si não se attribuir a nephrose chronica a um typo especial de desordem metabolica, não se pode explicar a lipoidemia, que em taes casos occorre. Sustentando este modo de ver, ou, em outras palavras, que a causa directa da hypercholesterinemia reside num deficiente metabolismo proteico, estão as constatações de Epstein e Hermann Lande, as quaes apontam uma certa relação causal entre o metabolismo basal e o conteúdo em cholesterina do sangue.

De modo geral pode-se dizer segundo estes estudos, que os estados que deprimem o processo metabolico do corpo causam um augmento do conteúdo cholesterinico do sangue, em quanto que aquelles que augmentam o metabolismo determinam uma diminuição. 
$\mathrm{Na}$ nephrose chronica, o metabolismo basal reduzido, subnormal, não é expressão de hypothyroidismo, mas sim de um imperfeito metabolismo proteico, motivado pela diminuição da energia dynamica especifica normalmente fornecida pelbs productos do catabolismo proteico.

$\mathrm{Na}$ nephrose chronica occorre uma baixa do metabolismo basal e os estudos sobre os processos metabolicos têm verificado a existencia de casos fronteiriços, onde de um lado estão os casos de nephrose chronica e de outro os de estados hypothyroideos e formas frustas de myxedema. Mas, se sob o ponto de vista bio-chimico a nephrose chronica e o myxedema apresentam pontos de contacto, a relação da glandula thyroide em uma e outra molestia é profundamente differente. No myxedema e no hypothyroidismo a thyroide desempenha papel genesico e causal visto aquellas entidades serem o resultado de uma deficiencia secretoria da glandula de grau variavel. Na nephrose chronica não existe evidencia de que a glandula thyroide seja lesada ou que sua funcção seja sub-normal embora a experimentação tenha mostrado que a quantidade de thyroidina exigida para restaurar o metabolismo da nephrose chronica ao normal é maior que aquella requerida no myxedema. Parece, todavia, diz Epstein, que a actividade thyroidiana na nephrose chronica mesmo normal ou augmentada é insufficiente para se oppôr a perturbação metabolica existente e a grande tolerancia exhibida pelos portadores de nephrose chronica para as doses relativamente altas de thyroidina e thyroxina, com o fim de restabelecer o metabolismo perturbado corrobora esta asserção. Talvez a semelhança de certos symptomas clinicos da nephrose chronica e do myxedema resida no facto de que em ambas entidades morbidas existe um disturbio do metabolismo proteico, perturbação que aliás é mais profunda na nephrose.

EDEma. - O édema é a manifestação clinica principal da nephrose chronica. A sua pathogenia, segundo Epstein, obedece a factores extra-renaes e reside nas modificações soffridas pelo esquilibrio osmotico reinante entre o sangue e os liquidos tecidulares e resulta das perturbações chimicas constatadas no estudo do sangue.

Após examinar as varias theorias propostas para a explicação do edema emitte Epstein a sua, que. resumidamente, é a seguinte: Normalmente se estabelece um sensivel equilibrio que regula as trocas liquidos entre o sangue e os tecidos e que é variavel segundo a actividade e exigencia dos tecidos. As forças que mantem este equilibrio são, de um lado, a pressão intracapillar, e, de outro, a força osmotica das proteinas e outras substancias dissolvidas no sangue. A perda continúa de albumina pela urina, se a mesma não for recompensada pela alimentação, accarreta, por fim, um empobrecimento da serum-proteina.

Este empobrecimento causa uma baixa da força osmotica do sangue e determina um accentuado disturbio no equilibrio osmotico que, uma vez rompido, não só favorece á passagem do liquido do 
sangue para os tecidos, mas tambem confere aos tecidos o poder de absorver e reter os liquidos. No edema nephrosico é a baixa da força osmotica que preside a sua formação, emquanto que no edema cardiaco ou nos edemas causados por obstrucção mecanica circulatoria, a causa immediata na genese reside no augmento da pressão intracapillar.

Ao lado do empobrecimento das serum proteina deve-se accrescentar outros factores, como o augmento na globulina e a lipoidemia que contribuem para modificar o estado colloidal do sangue, participando assim tambem na determinação do edema na nephrose.

Os estudos sobre o edema da guerra, nos quaes se constatou uma notavel diminuição da proteina do serum sanguineo e a producção experimental do edema em animaes sujeitos a baixa alimentação proteica, sustentam o modo de ver que estabelece relações causaes entre edema e empobrecimento do conteúdo proteinico do sangue.

Por tudo que acabamos de dizer, verifica-se que na nephrose chronica, se opera uma profunda perturbação metabolica da qual participa primariamente o metabolismo proteico e secundariamente o metabolismo dos lipoides. Assim o edema, a albuminuria, a lipoidemia (hypercholesterinemia), o baixo metabolismo basal, a diminuição do conteúdo proteinico do serum, e a inversão da relação albumina globulina são, na nephrose chronica, a expressão de um processo geral ou systemico determinado por uma perversão do metabolismo proteico, sendo as lesões de caracter puramente degenerativo, de ordem local, assestado sobre os rins, secundarias, ou antes, são a consequencia e não a causa do disturbio metabolico.

\section{EVOLUÇÃO - PROGNOSTICO — TRATAMENTO}

A evolução da nephrose chronica é lenta e gradual. Assim os symptomas a pouco e pouco vão apparecendo; o edema, principal manifestação clinica da molestia, apresenta uma phase de augmento seguida de outra estaccionaria para finalmente começar a se reduzir.

A albuminuria, que muitas vezes, marca o inicio do processo é de longa duração e rebelde ás vezes, ao tratamento. O prognostico da nephrose chronica pura é favoravel, as lesões renaes degenerativas sendo passiveis de regeneração completa. O desapparecimento dos symptomas clinicos não indicam entretanto a cura do caso, a persistencia da albuminia e a não restauração do conteúdo proteinico do sangue indicando se deva continuar com o tratamento. O tratamento requer muito tempo ás vezes um anno e mesmo mais para se obter um exito favoravel e cura completa. Em vista da interpretação pathogenica exposta as medidas therapeuticas a serem indicadas obedecem aos seguintes fins:

a) substituir a proteina perdida pelo plasma sanguineo, que resulta da albuminuria e representa um papel de importancia na retenção da agua e formação do edema. 
b) obrigar os tecidos a utilisarem as proteinas e accidentalmente reduzir a lipoidemia.

c) restabelecer o metabolismo normal.

Nos casos em que se quer agir mais rapidamente a transfusão de 500 grs. de sangue puro precedida da retirada de igual quantidade de sangue é um util subsidio de que se póde lançar mão visando aquelles fins apontados. Quando o estado da paciente não exige uma medida therapeutica rapida, a transfusão de sangue, bem como a retirada, dos liquidos colleccionados nas cavidades serosas ou no tecido subcubaneo, podem ser substituidas pelo regimem de Epstein ou seja a dieta alta em proteina e baixa em hydratos de carbono e gorduras.

A dieta rica em proteina visa augmentar o conteúdo proteinico do serum sanguineo que se acha reduzido assim como restabelecer a pressão osmotica do sangue.

A dieta pobre em hydratos carbono visa obrigar uma maior utilisação proteica por parte do organismo, bem como prevenir uma maior producção e retenção de agua o que é accidental no metabolismo dos hydratos de carbono; e, a dieta pobre em gordura visa impedir o augmento da lipoidemia já existente e tambem um maior aproveitamento das proteinas.

Os liquidos são restrictos á 1.000 a $1.500 \mathrm{cc}$ por dia, ou, o que é o mesmo, á quantidade que é fornecida pelos alimentos.

A quantdade de sal concedida na dieta é igual aquella necessaria para deixar os alimentos agradaveis ao paladar.

Visando ainda restabelecer o metabolismo alterado pela utilisação proteica emprega-se o extracto thyroidiano e a thyroxina. O emprego desses medicamentos para os quaes os nephroticos apresentam uma grande tolerancia supportando doses relativamente elevadas deve ser controlado pela dosagem do conteúdo cholesterinico do sangue.

A dosagem da cholesterina é um bom guia na administração do extracto thyroidiano e da thyroxina visto indicar o grau do aproveitamento proteico por parte do organismo. Emquanto existir hyypercholesterinimia não se verifica os symptomas thyreotoxicos a que estão sujeitos os individuos submettidos a administração d'aquelles productos therapeuticos. Na dieta rica em proteina e baixa em hydratos de carbono e limitada em gorduras, os generos alimenticios aconselhados são os proteicos preferivelmente isentos de gorduras e livres de lipoides como: carnes magras, carne de vitella, pernil, clara de ovos, ostras, gelatinas, favas, lentilhas, ervilhas, arroz, farinha de aveia, bananas, leite desnatado etc. Os alimentos totaes devem fornecer 1.280 a 2.500 calorias o que se consegue alimentando diariamente os pacientes com o regimem seguinte: Proteinas 120 a 240 grs; gorduras (inevitaveis) 20 a 40 grs; Hydratos de carbono 150 a 300 grs.

Naturalmente as circumstancias dos casos indicarão qual deve ser a conducta seguida, augmentando ou restringindo a dieta empregada. Epstein, com o uso da dieta por elle aconselhada, tem colhido 
optimos resultados. Assim elle observou o augmento do conteúdo proteinico do sangue e o desapparecimento da lipoidemia, seguindose estas modificações do chimismo sanguineo de uma eliminação de urina progressivamente augmentada com gradual desapparecimento da edema.

A albuminuria tambem se reduz chegando mesmo a desapparecer e o estado geral do paciente volta as condições normaes. Wordley, Mc Lean e De Wesselow dizem que o effeito obtido com a dieta de Epstein, isto é, que a remoção do edema e a diurese abundante, que se verifica, estão condiccionadas não ao augmento da proteina do sangue e sim ao augmento da uréa, que resulta do desmembramento da proteina administrada. Nesta conclusão elles se estribam no augmento da taxa da uréa sanguinea e na acção diuretica da uréa.

Epstein responde a esta objecção dizendo que o augmento da uréa do sangue é occassionada pela passagem no sangue d'aquelle producto, que se achava represado em todo o organismo nos tecidos encharcados.

Eis resumidamente, como pudemos fazer, o que encerram os 10 trabalhos de Albert A. Epstein que conhecemos sobre tão importante capitulo da pathologia.

E' um extracto que compillamos, como conseguimos deprehender da leitura, que fizemos dos escriptos d'aquelle scientista. O nosso resumo não envolve um unico commentario que tem sido feito sobre os trabalhos de Epstein e não comporta outras opiniões sobre o assumpto senão as do proprio Epstein. Não passa porisso mesmo, de uma simples divulgação scientifica.

São Paulo, Julho 927.

\section{B I B L I OG R A P H I A}

Albert A. Epstein: - Journal of Experimental Medicine: 1912 XVI - 719; 1913 - XVII - 444; 1914 - XX 334;

Albert A. Epstein: - The American Journal of Medical Science; 1917 - CLIV - 638; 1922 - CLXIII - 167

Albert A. Exstein: - The Journal of the Medical Association 1917 - LXIX - 444; 1926 - 87 - 913.

Albert A. Epstein: - Medical Clinics of North America - 1920 - IV - 145; 1922 - V - 1067

Epstein - Albert $A$. - e Lande Hermann - Archives of Internal Medicine - $1922-30-563$. 